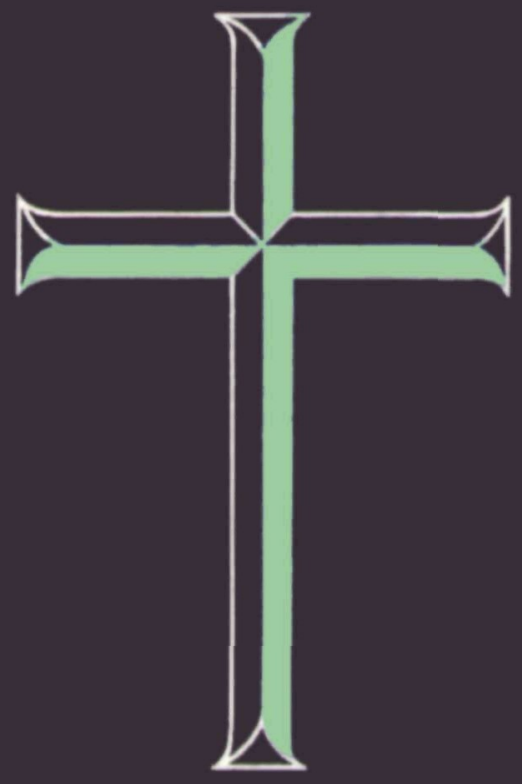

SCOTTISH JOURNAL $\theta^{\circ}$

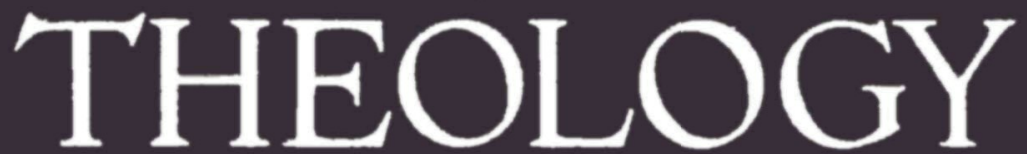

Vol. 19, No. 4 


\section{THE PASTORAL CARE OF THE DYING}

Library of Pastoral Care

\section{Norman Autton}

16s. 6d, net

This comprehensive guide will be of value not only to the clergy but also to Christian doctors, nurses, and social workers. For, as the author emphasizes, the ministry to the dying is not the province of the clergy alone, nor of those others professionally concerned, but of the family, the neighbour, and the fellow Christian.

\section{CREEDS, COUNCILS, AND CONTROVERSIES}

\section{J. Stevenson}

45s. net

Documents illustrative of the history of the Church A.D. 337-46r. The bulk of the work consists of 236 passages from contemporary authors, most in new or revised translations, each with introduction and commentary. Its usefulness is enhanced by the chronological tables and maps, features which were appreciated in the authors' former work, $A$ New Eusebius, which illustrates the history of the Church up to 337 A.D.

\section{THE RISE OF MORALISM}

\section{F. Allison}

508. net

Dr Allison argues that the position defended by Hooker, Andrewes, and Donne was opposed by Jeremy Taylor, Hammond, Thorndike, Bull, and Baxter; that the moralism of the last of these led to the deism of the 18th century and ultimately to the secularism of the 20th century. This decisive transition in English speaking theology provides a basis for understanding many modern dilemmas.

\section{PRAY AND LIVE}

\section{A. D. Duncan}

7s. 6d. net

In his Foreword Paul Singleton, C.R. writes, "I believe that this clear and able book will help many people to a deepening of their spiritual life and a clearer view of it against the background of the contemporary theological situation, and will release them from many of their fears and frustrations both in belief and in prayer." 


\title{
THE PHILOSOPHICAL JOURNAL
}

\section{Transactions of the Royal Philosophical Society of Glasgow}

\begin{abstract}
In the shadow of the Bomb a technological revolution is gathering momentum. Extreme specialisation has rendered many acutely aware of their isolation in a chosen groove of knowledge. They feel that one way to counter their narrowness of outlook is to make a conscious effort to acquaint themselves with essential advances in other fields than their own.

The Society provides through its lectures and discussions a meeting-ground for all such as are willing to share with others their own particular knowledge; and through The Philosophical Journal the Society publishes its proceedings in the hope of reaching a wider audience.

The Journal publishes not only papers given before the Society but also outside contributions on topics within the general aims of the Society.
\end{abstract}

\section{CONTENTS}

Volume 3 January 1966

Number 1

The Origin of the Constellations

Domestic Life in Sardinia

Refrigeration below $1^{\circ}$ Kelvin

Science, Religion and Theology

Sources and Estuaries of Abstraction

The Logic of Value Conflicts

Reviews

Karl M. Abenheimer, L. Pompa

Volume 3 July 1966

Number 2

Joseph Lister: Surgeon-Biologist Ambiguous Creation

Theosophy and the Age of Science

Shipbuilding Today

Michael $W$. Ovenden

M. F. M. Meiklejohn

E. Mendoza

Trant B. Luard

$M$. Gordon

John De Lucca

Significance of the Novel in French-speaking Black Africa

Antony C. Brench

On Certain Statistical Features of the Pauline Epistles

Sir Charles Illingworth

John A. M. Rillie

J. L. Shank

Sir William Lithgow, Bt.

Review

M. Levison, A. Q. Morton and W. C. Wake

Review

L. Pompa

This Journal is published half-yearly in January and July. The annual subscription is 20s. (U.S.A. \$3.50), single number 12s. 6d. (U.S.A. $\$ 2.00)$. Orders and subscriptions may be sent to any bookseller or direct to:

\section{OLIVER \& BOYD LTD}

Tweeddale Court, 14 High Street, Edinburgh 1 


\section{THE}

\section{'UNWRITTEN' AND 'SECRET' APOSTOLIC TRADITIONS IN THE THEOLOGICAL THOUGHT OF ST. BASIL OF CAESAREA}

By The Reverend Dr. AMAND DE MENDIETA, M.A., B.D.

Edited by Professor T. F. Torrance

In this book the author, drawing from all the relevant texts of the treatise 'On the Holy Spirit', gives an interpretation of the theological thought of St. Basil of Caesarea. In order to investigate systematically St. Basil's theology he has to discuss four different subjects. First he deals with the use of unscriptural words in the writings against heretics. Secondly he analyses all the passages of the treatise in which the adjective 'unwritten' occurs, in order to define its precise meaning in connection with such words as traditions, witnesses, customs, and sacraments. Thirdly on the basis of the available evidence, he considers what St. Basil means by the 'secret' or 'esoteric' character which he attributes to the church's 'unwritten' traditions. Finally he expounds the thought of the Bishop of Caesarea concerning the 'apostolic' or 'patristic' origin of the church's 'unwritten' traditions.

10s. 6d.

\section{OLIVER \& BOYD}




\section{SCOTTISH JOURNAL OF THEOLOGY OCCASIONAL PAPERS}

General Editors: T. F. Torrance and J. K. S. Reid

No. 1 A BIBLICAL APPROAGH TO THE DOGTRINE
OF THE TRINITY by G. A. F. Knight

6s. net

No. 2 ESCHATOLOGY

by William Manson, G. W. H. Lampe, T. F. Torrance and W. A. Whitehouse

6s. net

No. 3 ROYAL PRIESTHOOD

by T. F. Torrance

9s. net

No. 4 THE BIBLIGAL DOGTRINE OF THE MINISTRY by J. K. S. Reid 5s. net

No. 5 CHRIST AND ADAM

by Karl Barth

6s. net

No. 7 THE APOSTOLIC MINISTRY
by Arnold Ehrhardt
8s. $6 d$. net

No. 8 GOD, GRAGE AND GOSPEL

by Karl Barth

8s. $6 d$. net

No. 9 WAS GHRIST'S DEATH A SAGRIFICE?

by Markus Barth

7s. $6 d$. net

No. 10 KARL BARTH'S TABLE TALK.

by John D. Godsey, Ed. $\quad$ gs. $6 d$. net

No. 11 DEEDS AND RULES IN CHRISTIAN ETHIGS by Paul Ramsey

Ios. $6 d$. net

No. 12 A COMMENTARY ON ROMANS 12-13

by C. E. B. Cranfield Ios. $6 d$. net 


\section{SCOTTISH JOURNAL OF THEOLOGY}

Volume Nineteen 1966 


\title{
SCOTTISH JOURNAL
}

\author{
of \\ THEOLOGY
}

Volume Nineteen

1966

EDITORS:

T. F. TORRANCE, M.B.E., D.D., D.ThÉol., DR Theol.

J. K. S. REID, T.D., D.D.

\author{
OLIVER \& BOYD LTD. \\ EDINBURGH: TWEEDDALE COURT \\ LONDON: 39A WELBECK STREET, W.I
}


PRINTED IN GRRAT BRITAIN FOR THE PUBLISHRRS

BY ROBBRT CUNNINGHAM AND SONS LTD., ALVA 


\title{
SCOTTISH JOURNAL
}

\author{
of \\ THEOLOGY
}

Vol. 19, No. 4

December, 1966

EDITORS:

Rev. Professor T. F. TORRANCE

Rev. Profzssor J. K. S. REID

\section{OLIVER \& BOYD LTD.}

EDINBURGH: TWEEDDALE COURT

LONDON: 39A WELBECK STREET, W.1 


\title{
SCOTTISH JOURNAL OF THEOLOGY
}

\section{Published Quarterly}

\author{
Editors: \\ Rev. Prof. T. F. Torrance, M.B.E., D.D., D.Théol., Dr Theol., \\ 37 Braid Farm Road, Edinburgh, to (Telephone MOR 3050) \\ Rev. Pror. J. K. S. ReID, T.D., D.D., \\ Don House, 46 Don Street, Aberdeen (Telephone 4ז526) \\ Consulting Editors: \\ Very Rev. Principal J. H. S. Burleigh, D.D., B.Litt. \\ Chairman of Directors \\ Rev. Prot. David Calrns, D.D. \\ Rev. Prof. N. W. Porteous, D.D. \\ Rev. Prof. A. M. Hunter, Ph.D., D.Phll., D.D.

\section{Directors:} \\ The above-named together with \\ Rev. Prof. E. P. Dickie, M.C., D.D. \\ Rev. J. Heron, B.D., S.T.M. \\ Rev. Stewart Mechie, M.A., D.D. \\ Rev. T. M. Murchison, M.A., D.D. \\ Rev. Prof. J. A. McFadden, B.D. \\ Rev. J. W. Stevenson, M.A., D.D. \\ Rev. J. B. Torrance, B.D. \\ Rev. Prof. R. S. Wallace, M.A., B.Sc., Ph.D. \\ Rev. D. Brian Thompson, B.A., Th.M., Secretary
}

CONTRIBUTIONS are invited from members of all branches of the Christian Church.

EDITORIAL CORRESPONDENCE-MSS and Books for review should be sent to one of the Editors.

BUSINESS CORRESPONDENCE should be sent to the Registered Office.

PRICE: Six Shillings and Sixpence (U.S.A. and CANADA \$1.00) per copy, post free.

ANNUAL SUBSCRIPTION: Twenty-four Shillings, post free. (U.S.A. and CANADA \$4.00.)

(listed in Index to Religious Periodical Literature, Chicago)

PUBLISHED BY OLIVER AND BOYD FOR SCOTTISH JOURNAL OP THROLOGY LTD.

Registered Office: TWEEDDALE COURT, EDINBURGH, 1 


\section{CONTENTS}

Ten Articles on the Freedom and Service of the Ghurch; and an Evaluation by Karl Barth

PAGE

he Finality of Christ and Humanity, by the Rev. John W.

Fraser, B.E.M., M.A., B.D., Farnell, Brechin

$3^{85}$

399

Karl Barth's Doctrine of the Sabbath, by the Rev. James Brown, D.D., Stranraer

LORd Also of the Sabrath, by the Rev. James W. Leitch, B.D., Dr Theol., Basel

Discernment Situations: Some Philosophical Dificulties, by the Rev. W. D. Hudson, M.A., B.D., Ph.D.

Indian Christian Thinking in Relation to Christ, by the Rev.

R. H. S. Boyd, M.A., B.D., Ph.D., Ahmedabad, India

The Nature and Function of Adult Ghristian Education in The Ghurch, by the Rev. John Gray, M.A., B.D., Edinburgh

Article Review:

Bernard Towers: Teilhard de Chardin; Christopher F. Mooney: Teilhard de Chardin and the Mystery of Christ; Pierre Teilhard de Chardin: Man's Place in Nature, by the Rev. Dr Cameron Dinwoodie, Langholm

Book ReVIEWS:

John Wisdom: Paradox and Discovery, by Professor Ronald W. Hepburn, Edinburgh

Oscar Cullmann: Heil als Geschichte, by the Rev. Dr H. Hartwell, London

F. W. Dillistone (ed.): Myth and Symbol, by the Rev. J. Heywood Thomas, Durham

Kenneth Hamilton: God is Dead, by the Rev. Professor David Cairns, Aberdeen

David E. Jenkins: Guide to the Debate about God, by the Rev. Dr J. A. B. Holland, Sydney

M. Noth: Exodus, by the Rev. Professor John Gray, Aberdeen

James Barr: Old and New in Interpretation, by the Rev. Dr N. H. Snaith, Thetford

The Greek New Testament, by the Rev. Principal Matthew Black, St. Andrews

Walter Schmithals: Paul and James; Ferdinand Hahn: Mission in the New Testament, by the Rev. Neil Alexander, Glasgow 
Bruce M. Metzger: The Text of the New Testament; Stephen Neill:

The Interpretation of the New Testament $1862-196 \mathrm{r}$, by the Rev.

Dr R. McL. Wilson, St. Andrews

Paul Hitz: To Preach the Gospel, by the Rev. Dr E. S. P. Heavenor, Crieff

Heinrich Ott: Theology and Preaching, by the Rev. Dr E. S. P.

Heavenor, Crieff

Roger Mehl: Images of Man, by the Rev. Kenneth MacKenzie, Edinburgh

John Huxtable: Christian Unity, by the Rev. John G. Levack, Prestonkirk, East Linton

498

Raphael Loewe: The Position of Women in Judaism, by the Rev. John Heron, Stevenston

Donald J. Bruggink and Carl H. Droppers : Christ and Architecture, by the late Ian G. Lindsay

A. R. C. Leaney: The Rule of Qumran and its Meaning, by the Rev.

Dr R. McL. Wilson, St. Andrews

Geoffrey Parrinder: Jesus in the Qur'an, by the Rev. J. M. Ritchie, Mombasa

John Wilkinson: The Supper and the Eucharist, by the Rev. Dr John

A. Lamb, Edinburgh

Books Recerved

\section{IN THIS ISSUE}

Articles on the East German Church on Freedom and Service the Finality of Christ the Sabbath

Discernment Situations

Indian Thinking about Christ

Adult Christian Education

An Article Review on Teilhard de Chardin

Among the books reviewed are works on the Logic of God

Salvation History

Symbols

God is Dead

a new Greek Testament

Theology and Preaching

Church Architecture 